\title{
CHROMOSOME STUDIES IN TURKISH SPECIES OF NONEA (BORAGINACEAE): THE ROLE OF POLYPLOIDY AND DESCENDING DYSPLOIDY IN THE EVOLUTION OF THE GENUS
}

\author{
F. Selvi*† \& M. Bigazzi*
}

\begin{abstract}
Seven Turkish species of Nonea Medik. (Boraginaceae-Boragineae) were studied karyologically using material collected in the field from wild populations. Somatic chromosome number and karyotype morphology were determined for each species using orcein staining. Nonea pulmonarioides is diploid with $2 n=20$, though some cells showed $2 n=19$. Nonea anchusoides turned out to be tetraploid with $2 n=4 x=40$, while $N$. macrosperma was characterized by a hexaploid complement of $2 n=6 x=60$. These data indicate polyploidy based on $x=10$ as a major mechanism of speciation in the perennial members of the genus. Among the annuals, $N$. echioides and $N$. versicolor showed $2 n=16$, while $N$. obtusifolia and $N$. lutea were characterized by $2 n=20$ and $2 n=14$, respectively. The results reveal that $x=10$ is more frequent in Nonea than previously realized, and that it may be the ancestral haploid number of diploid endemics of (sub)alpine habitats in the Pontic-Caucasian mountain system. The hypothesis is here proposed that the base numbers $x=9, x=8$ and $x=7$, progressively prevalent in the annual species from lower altitudes, may have originated through descending dysploidy associated with the tendency to shorten the life cycle as an adaptation to arid habitats.
\end{abstract}

Keywords. Boragineae, cytotaxonomy, karyology, Nonea, Turkish flora.

\section{INTRODUCTION}

The genus Nonea Medik. (Boraginaceae tribe Boragineae Bercht. \& J. Presl) includes about 35 taxa distributed in the Tethyan region from western Asia to the Iberian Peninsula and Morocco. Its main centre of diversity stretches from the PonticCaucasian mountain system to the Anatolian and Irano-Turanian highlands, while fewer species occur in Europe and in the Mediterranean, especially along the North African coast. Turkey is the richest country, with approximately 21 species representing more than $50 \%$ of the whole genus (Baytop, 1979; Selvi \& Bigazzi, 1999, 2001).

On the whole, the systematic and evolutionary aspects of Nonea are still poorly known and its classification relies on out-dated treatments not yet revised and improved by modern studies. Even its delimitation with respect to closely related genera such as Paraskevia W. Sauer \& G. Sauer and Elizaldia Willk. is subtle and

\footnotetext{
* Dipartimento di Biologia Vegetale dell’Università, Via La Pira 4, 50121 Firenze, Italy.
}

† E-mail: selvi@unifi.it 
still debated by some authors. Johnston (1924), perhaps the most authoritative worker on the Boraginaceae, considered Nonea as no more than an 'annual' xerophytic section of Pulmonaria L.

Much of this uncertainty exists because the genus is morphologically and ecologically heterogeneous and contains distinct lineages showing different combinations of structural characters. This applies also to the morphology and ultrastructure of pollen grains, whose remarkable variation has been recently classified into five palynological types (including Elizaldia) only partially corresponding to the groups of taxa based on general morphology (Bigazzi \& Selvi, 1998). A similar degree of variation has also been observed in the form of the stigma, the architecture of its receptive surface, and the structure of the papillae, leading to the recognition of six stigmatic types largely corresponding to the pollen types (Bigazzi \& Selvi, 2000).

Only two karyological studies with discussion have been carried out on Nonea, the first by Grau (1971) on five annual species (considering Elizaldia), and the second, more recently, by Luque (1995) on the three taxa native to Spain. Other reports in the literature relate to sporadic counts, often obtained from cultivated plants. To our knowledge, the total number of taxa for which chromosome numbers have been published is 12, with a large prevalence of European and W Mediterranean annual species. Though still largely incomplete, this picture was sufficient to show that chromosome numbers in Nonea are as diverse as some structural characters, providing a valuable source of information to assess interspecific relationships. The genus is 'polybasic', with base chromosome numbers of at least $x=7,8,10$ and 15. Such karyological diversity has also emerged in a recent revision of the Nonea pulla DC. group in Turkey, where chromosome analysis of four taxa contributed substantially to the taxonomic understanding of this critical group (Selvi \& Bigazzi, 2001). That study allowed $x=9$ to be added to the series of base numbers, as this was found in the polyploid $N$. persica Boiss. with $2 n=36$. To our knowledge, $N$. monticola (Rech.f.) Selvi \& Bigazzi, N. polychroma Selvi \& Bigazzi, N. persica Boiss. and N. atra Griseb. are the only Turkish species in which wild populations have been studied karyologically. This paper is a further contribution to the subject, as it describes the karyotypes of seven Turkish members of the genus $-N$. anchusoides Boiss. \& Buhse, $N$. echioides (L.) Roem. \& Schult., N. lutea (Desr.) DC., N. macrosperma Boiss. \& Heldr., N. obtusifolia (Willd.) DC., N. pulmonarioides Boiss. \& Balansa, and N. versicolor (Steven) Sweet - and, drawing also on other sources of evidence, proposes some ideas on chromosome evolution and speciation mechanisms.

\section{Materials and Methods}

\section{Plant material}

All karyological analyses were carried out on material gathered in the wild by the authors, using seeds for annual species and plants for perennial species. The three perennials are currently cultivated in the Botanical Garden of Florence University. 
Only one population for each species was analysed, except for $N$. macrosperma and $N$. versicolor with two populations each. Two plants and no fewer than 8-12 root tips per individual were examined for the perennial taxa. About 15 germinating seeds were examined for each annual taxon. Voucher specimens are in the authors' personal collection in FI; duplicates are at E. Provenances are given for all taxa examined.

Perennial species:

Nonea anchusoides Boiss. \& Buhse: B9 Ağri, meadows around the village of Güneykaya c.8km W of Eleșkirt towards Horasan, c.1850m, 29 v 2000, Bigazzi \& Selvi 00.22.

N. macrosperma Boiss. \& Heldr.: A5 Amasya, stony, fallow fields on limestone mountains c.5km N of the town, 750m, 21 vi 1998, Bigazzi \& Selvi 98.015; C4 Antalya-Içel, Taurus Mt., stony fallow fields close to the village of Akpinar on the road to Anamur, limestone, c. $1500 \mathrm{~m}$, 7 vi 1997, Bigazzi \& Selvi 97.033.

N. pulmonarioides Boiss. \& Balansa: A9 Artvin-Kars, Çam Geçidi between Şavşat and Ardahan, alpine slopes and meadows, c.2550m, 18 vi 1998, Bigazzi \& Selvi 98.013.

Annual species:

Nonea echioides (L.) Roem. \& Schult.: C4 Konya, stony fields on limestone 10km E of Ermenek, c.1200m, 7 vi 1997, Bigazzi \& Selvi 97.032.

N. lutea (Desr.) DC.: A9 Artvin, ruderal places at the NE periphery of the town, c. $600 \mathrm{~m}, 23$ v 00, Bigazzi \& Selvi 00.34.

N. obtusifolia (Willd.) DC.: C4 Antalya, fallow fields in Pinus brutia forest in the hills around Gebiz, c.100m, limestone, 8 vi 1997, Bigazzi \& Selvi 97.041.

N. versicolor (Steven) Sweet: A9 Kars, rocky igneous slopes along the road between Ardahan and Kars, c.1600m, 18 vi 1998, Bigazzi \& Selvi 98.021; A9 Kars, fields around the E shore of Çildir Gölu, c.1850m, 26 v 2000, Bigazzi \& Selvi 00.08.

\section{Chromosome analysis}

Seed germination occurred almost exclusively in soil out-of-doors and in low percentages; no results were obtained in Petri dishes, except with the annuals $N$. obtusifolia and $N$. echioides. Most species required chilling for c. 3 months at $2-3^{\circ} \mathrm{C}$. Root tips from potted seedlings were pretreated with $0.002 \mathrm{M}$ 8-hydroxyquinoline or $0.05 \%$ colchicine for 2.5 hours at room temperature and then fixed overnight in ethanol:glacial acetic acid 3:1. When necessary, they were preserved in $70 \%$ ethanol at $3-4^{\circ} \mathrm{C}$ until preparation. They were then rinsed in distilled water, hydrolysed in $1 \mathrm{~N} \mathrm{HCl}$ at $60^{\circ} \mathrm{C}$ for 6-7 minutes, stained in lactopropionic orcein overnight, dissected and squashed on clean glass slides in a drop of $45 \%$ acetic acid (Dyer, 1979).

For each species, the best metaphase figures were photographed and idiograms prepared on enlarged prints by measuring the overall length of the chromosomes and of their arms and satellites. The centromeric index was then calculated as the long-arm:short-arm ratio and chromosomes classified according to the terminology 
of Levan et al. (1964): $\mathrm{M}=$ exact metacentric $(r=1), \mathrm{m}=$ metacentric $(r=1.10-1.69)$, $\mathrm{sm}=$ submetacentric $(r=1.70-2.99), \mathrm{st}=$ subtelocentric $(r=3.00-6.99)$. The intrachromosomal asymmetry index $\left(A_{1}\right)$ was calculated according to the formula proposed by Romero Zarco (1986), while the interchromosomal index $\left(A_{2}\right)$ was measured as the ratio of standard deviation of chromosome length to mean chromosome length. In the idiograms, pairs of homologous chromosomes were arranged according to length, within each category of centromeric position. For each species, length and asymmetry values were averaged from all the preparations examined.

\section{Results AND Discussion}

Somatic and haploid chromosome numbers, ploidy levels, karyotype formulae, intraand interchromosomal asymmetry indexes and mean chromosome length for each species investigated are given in Table 1.

Nonea anchusoides. Sect. Nonea (sect. Cryptanthera DC.). This rare species, which mostly occurs on the high mountains between Lake Urmia in Iran, Lake Van in Turkey, and the Rawanduz region in N Iraq, was characterized by a chromosome complement of $2 n=40$, whose length ranged between about 2.8 and $3.4 \mu \mathrm{m}$ (Fig. 1). If $x=10$ is assumed to be the base number, $N$. anchusoides is tetraploid with $n=20$. Its karyotype consisted of one pair of exact metacentrics, 10 pairs of metacentrics, eight pairs of submetacentrics and just one pair of subtelocentrics; no satellites were observed. As a result, the intrachromosomal asymmetry $\left(A_{1}\right)$ was relatively low; differences in size between chromosomes were also small, accounting for a low $A_{2}$ index. The chromosomes showed banding with deeply stained heterochromatic regions alternating with euchromatic segments.

TABle 1. Somatic chromosome number $(2 n)$, base number and ploidy level, karyotype formula, intra- $\left(A_{1}\right)$ and interchromosomal $\left(A_{2}\right)$ asymmetry indexes and mean chromosome length $(L)$ of taxa investigated

\begin{tabular}{lccllll}
\hline \hline Nonea species & $2 n$ & $\begin{array}{c}\text { Base number } \\
\text { (ploidy level) }\end{array}$ & Formula & $A_{1}$ & $A_{2}$ & $L(\mu \mathrm{m})$ \\
\hline anchusoides & 40 & $10(4 x)$ & $2 \mathrm{M}+20 \mathrm{~m}+16 \mathrm{sm}+2 \mathrm{st}$ & 0.32 & 0.13 & 3.1 \\
echioides & 16 & $8(2 x)$ & $2 \mathrm{M}+2 \mathrm{~m}+8 \mathrm{sm}+4 \mathrm{st}$ & 0.45 & 0.13 & 1.9 \\
lutea & 14 & $7(2 x)$ & $2 \mathrm{~m}+6 \mathrm{sm}+2 \mathrm{sm}^{\mathrm{SAT}}+4 \mathrm{st}$ & 0.54 & 0.17 & 2.0 \\
macrosperma & 60 & $10(6 x)$ & $10 \mathrm{M}+20 \mathrm{~m}+26 \mathrm{sm}+4 \mathrm{st}$ & 0.37 & 0.14 & 2.6 \\
obtusifolia & 20 & $10(2 x)$ & $10 \mathrm{M}+8 \mathrm{~m}+2 \mathrm{sm}^{\mathrm{m}}$ & 0.17 & 0.08 & 1.8 \\
pulmonarioides & 20 & $10(2 x)$ & $4 \mathrm{~m}+10 \mathrm{sm}+2 \mathrm{sm}^{\mathrm{SAT}}+4 \mathrm{st}$ & 0.52 & 0.14 & 3.2 \\
versicolor & 16 & $8(2 x)$ & $6 \mathrm{M}+6 \mathrm{~m}+4 \mathrm{sm}$ & 0.31 & 0.12 & 1.9 \\
\hline \hline
\end{tabular}

Terminology from Levan et al. (1964): $\mathrm{M}=$ exact metacentric $(r=1), \mathrm{m}=$ metacentric $(r=1.10-1.69), \mathrm{sm}=$ submetacentric $(r=1.70-2.99), \mathrm{st}=$ subtelocentric $(r=3.00-6.99) . A_{1}$ (intrachromosomal asymmetry index) calculated from formula proposed by Romero Zarco (1986); $A_{2}$ (interchromosomal index) measured as ratio of standard deviation of chromosome length to mean chromosome length. 

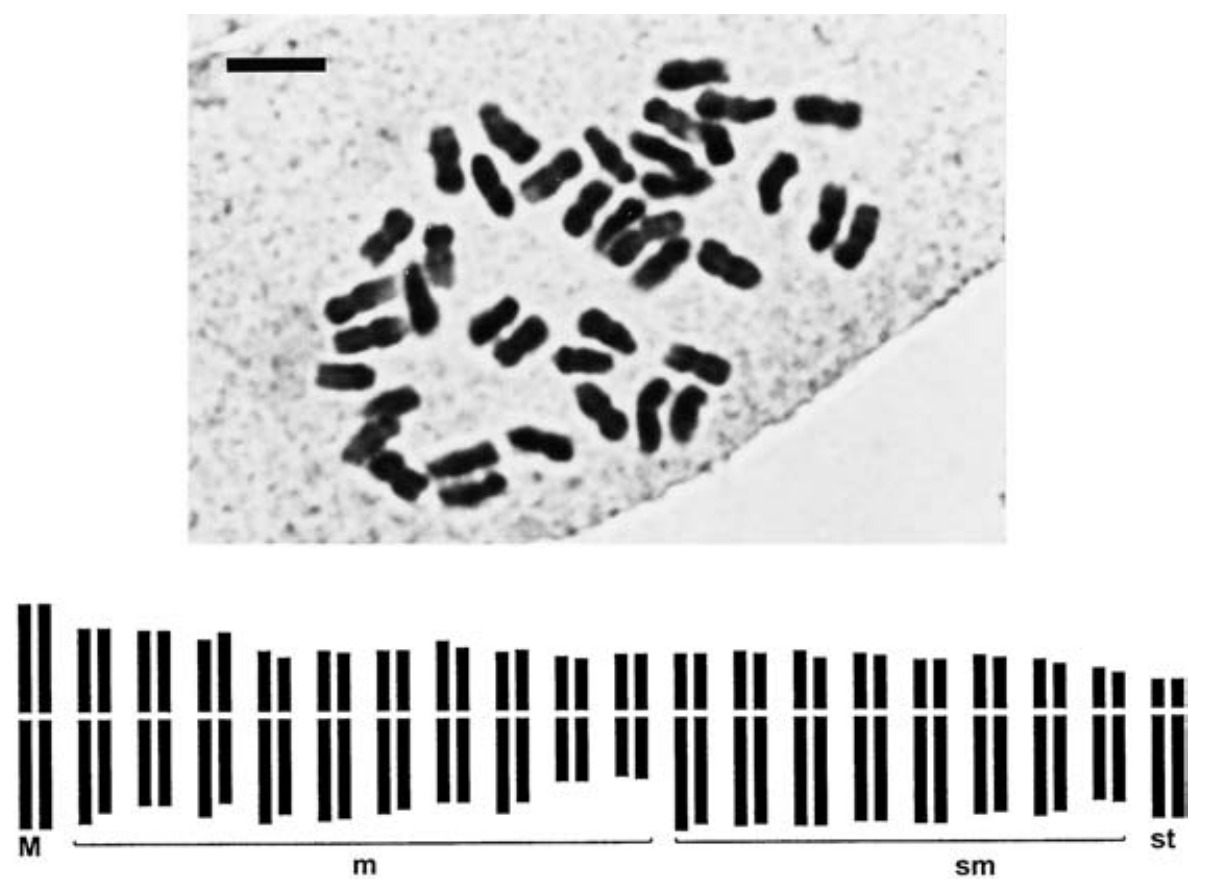

FIG. 1. Metaphase plate and idiogram of Nonea anchusoides $(2 n=40)$. Scale bar $=5 \mu \mathrm{m}$.

N. pulmonarioides. Sect. Nonea (sect. Cryptanthera DC.). This is a Euxine endemic related to the Transcaucasian $N$. intermedia Ledeb. and previously known only from the type locality (A9 Rize, Çimil Dağ in the group of Kaçkar Dağlari, Pontic Alps). The population sampled in the new locality (Çam Geçidi between Şavşat and Ardahan in NE Anatolia) showed $2 n=20$, with four metacentrics, 12 submetacentrics, of which one pair had microsatellites (diameter smaller than chromosome diameter) on the short arms, and four subtelocentrics (Fig. 2a). However, some cells in most root tips examined showed a hypoploid complement of $2 n=19$, with one satellited submetacentric being apparently lost (Fig. 2b). This species, not previously investigated karyologically due to its rarity, is therefore basically diploid with $n=$ 10 but seems to be characterized by a phenomenon known as 'aneusomaty', i.e. the occurrence of different chromosome numbers in somatic cells of the same individual plant (D'Amato, 1995).

The chromosomes were medium sized, their length ranging from 3.0 to $3.4 \mu \mathrm{m}$; the $A_{1}$ index was substantially higher than in $N$. anchusoides as a consequence of the prevalence of sm and st chromosomes. In early metaphase, most chromosomes showed heterochromatic segments with differential orcein stainability due to differing degrees of condensation at the time of fixation.

The presence of one pair of submetacentrics with microsatellites (at least in the cells with $2 n=20$ ) was observed in this species only, while macrosatellites also occurred in $N$. lutea (see below). Chromosomes with satellites seem uncommon in 

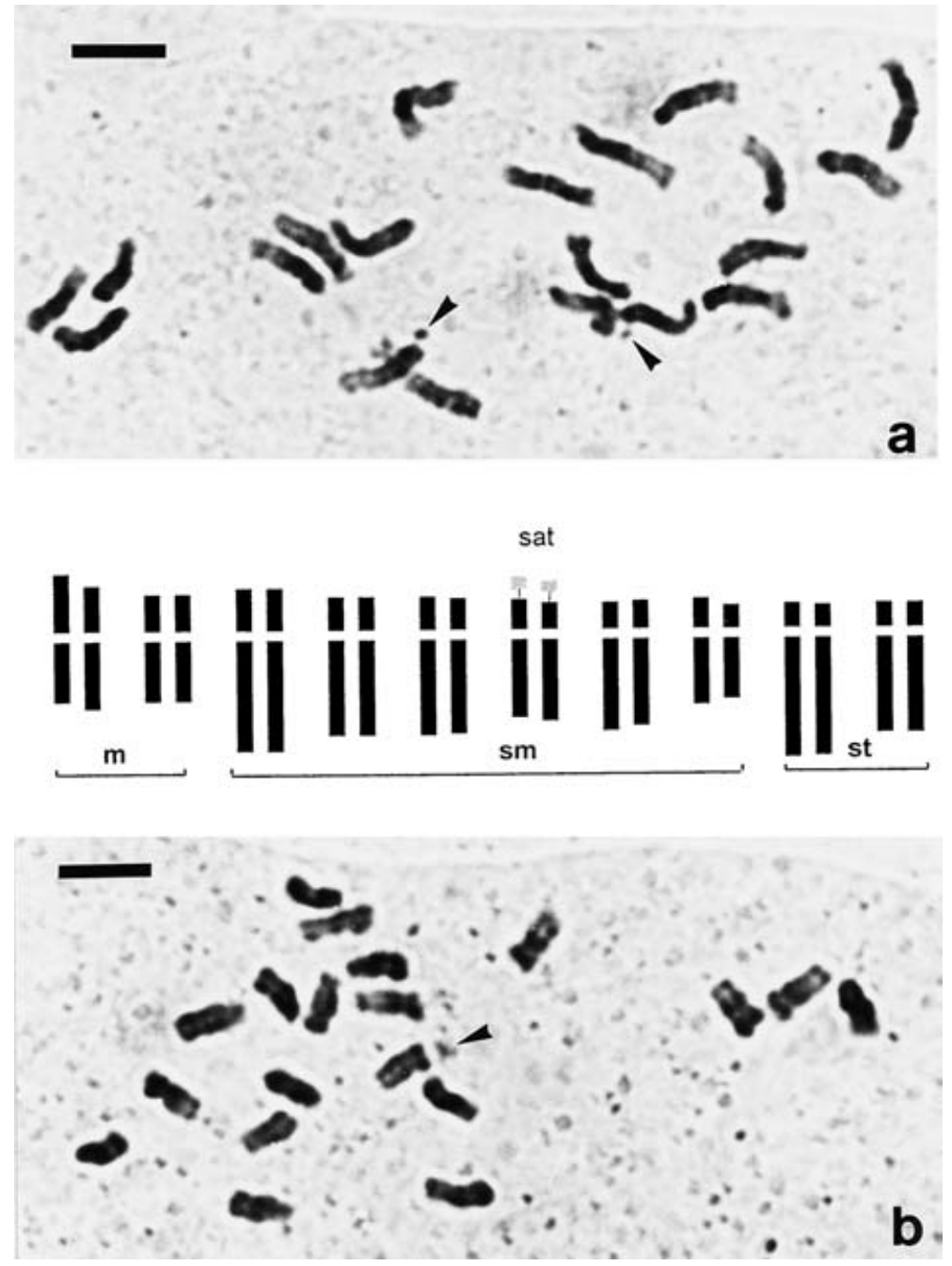

FIG. 2. Nonea pulmonarioides: a, prometaphase chromosomes and idiogram with $2 n=20$; b, metaphase plate showing $2 n=19$. Arrows indicate satellites. Scale bars $=5 \mu \mathrm{m}$.

Nonea; this contrasts with Pulmonaria, where they occur in several species (Sauer, 1987; Luque, 1989).

N. macrosperma. Sect. Nonea (sect. Cryptanthera DC.). This is a distinctive endemic of central Anatolia with pale yellow flowers and large mericarps. It showed a chromosome complement of $2 n=60$, with 10 exact metacentrics, 20 metacentrics, 26 submetacentrics and four subtelocentrics; no satellites were seen (Fig. 3). Heterochromatic segments seemed less abundant in this species. Karyotype asymmetry was comparable to that of $N$. anchusoides. Compared with $N$. pulmonarioides and $N$. anchusoides, the chromosomes were slightly smaller, their length ranging between about 2.2 and 

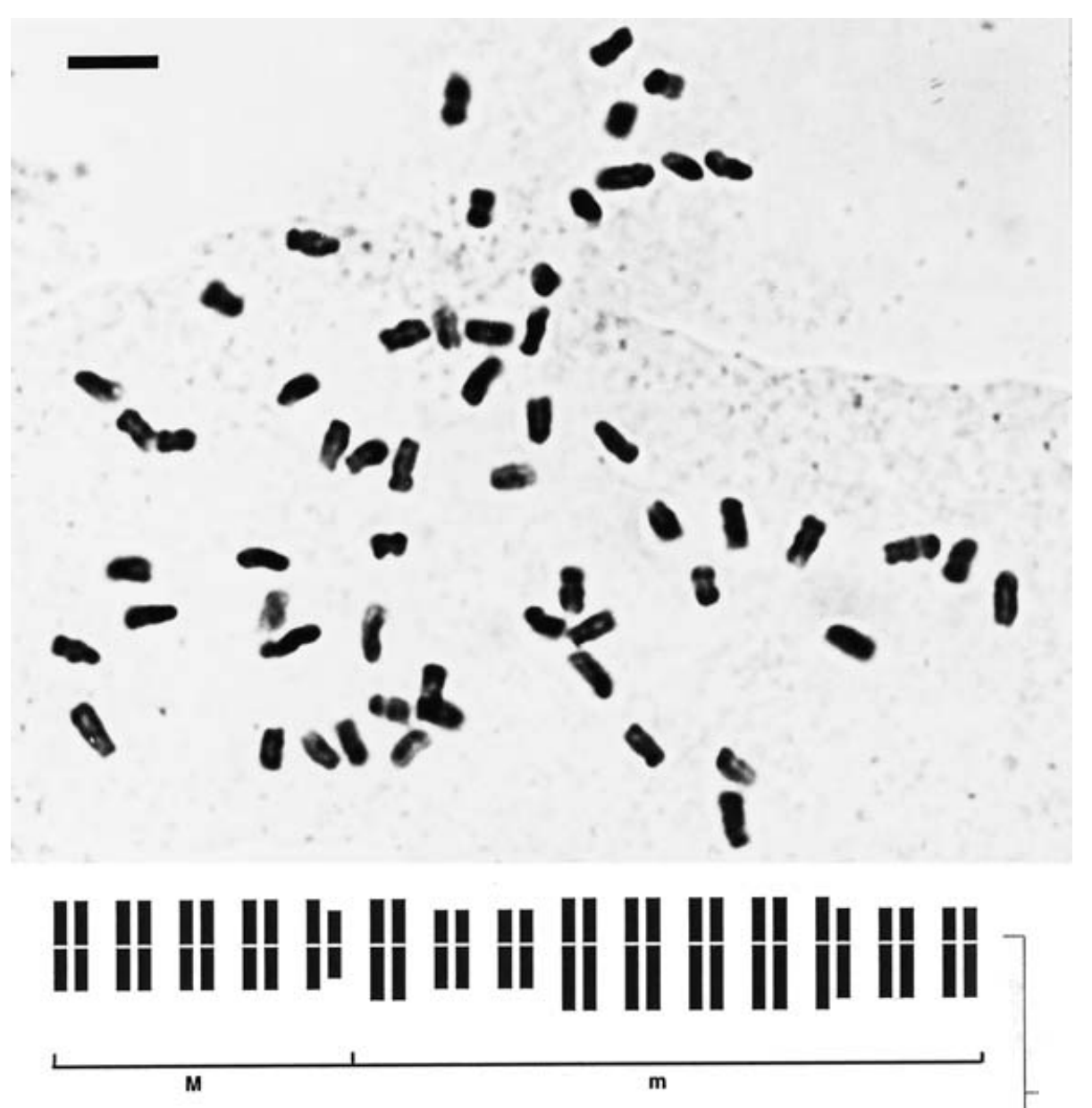

\section{if if if if if if it it it it it if ii ii if}

sm

st

FIG. 3. Metaphase plate and idiogram of Nonea macrosperma $(2 n=60)$. Scale bar $=5 \mu \mathrm{m}$.

$3.0 \mu \mathrm{m}$. If $x=10$ is assumed to be the primary base number, N. macrosperma is a hexaploid with $n=30$.

N. lutea. This species, a member of sect. Orthocaryum DC., is distributed in the Irano-Turanian area. It showed a complement of $2 n=14$ chromosomes with distinct heterochromatic regions and size ranging from 1.8 to $2.2 \mu \mathrm{m}$ (Fig. 4a). The karyotype consisted of one pair of metacentrics, eight submetacentrics, of which two had macrosatellites (diameter about the same as chromosome diameter) on the short arms, and 

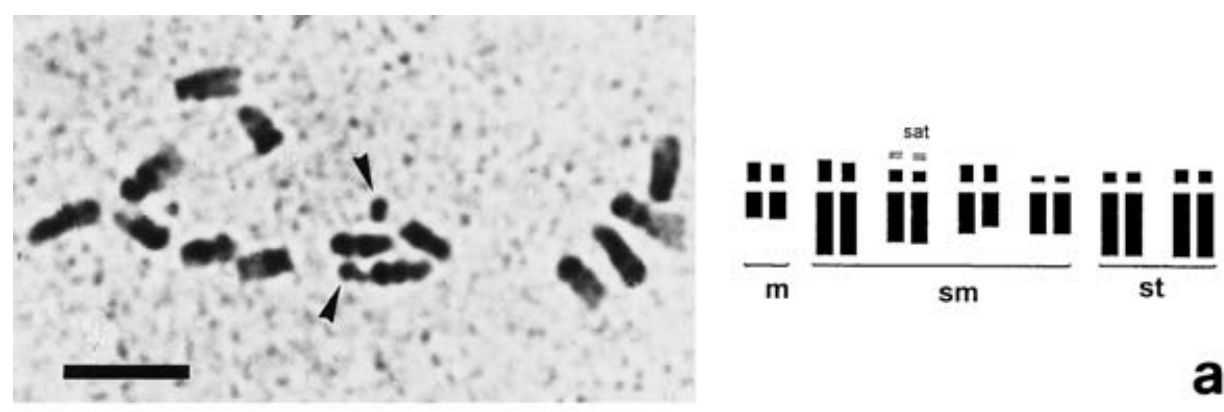

a

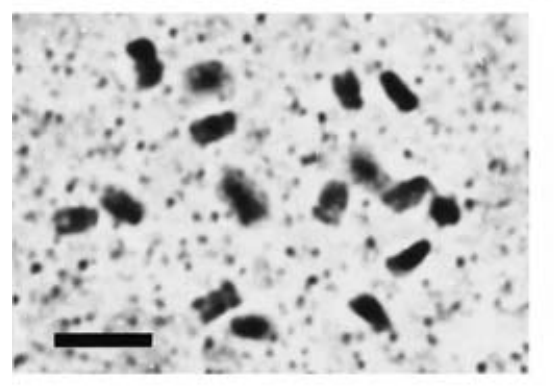

\section{It it if it if it it}
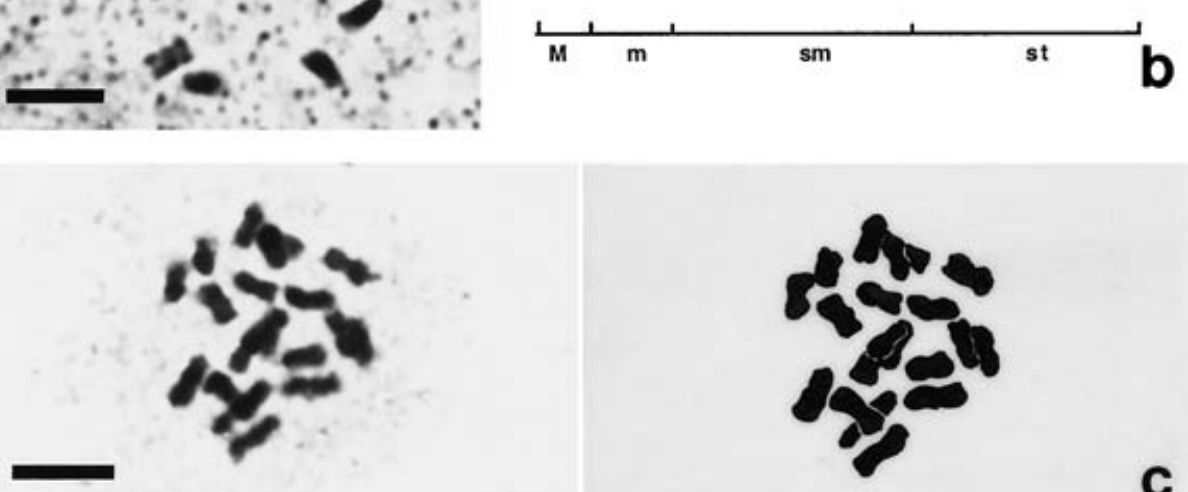

C

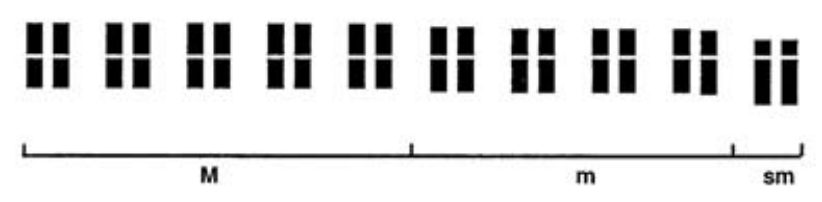

FIG. 4. Metaphase plates and idiograms of: a, Nonea lutea $(2 n=14)$, arrows indicate satellites; b, $N$. echioides $(2 n=16) ; \mathrm{c}, N$. obtusifolia $(2 n=20)$. Scale bars $=5 \mu \mathrm{m}$.

two pairs of subtelocentrics. Both indexes of karyotype asymmetry were higher than in the other taxa examined. Macrosatellites were apparently not observed in previous reports on this species, all of which confirm the diploid number $2 n=14$ obtained from cultivated plants (Strey, 1931; Britton, 1951) and a wild Iranian population (Grau, 1971).

N. echioides. This widespread Mediterranean species with white flowers and reniform mericarps (sect. Cyrtocaryum DC.) showed $2 n=16$ small chromosomes measuring 
1.8-2.1 $\mu \mathrm{m}$ (Fig. 4b). The complement consisted of two exact metacentrics, two metacentrics, eight submetacentrics and four subtelocentrics apparently lacking satellites. Intrachromosomal asymmetry was slightly higher than in most of the other species examined here, while the $A_{2}$ index was comparable. Heterochromatic regions were not clearly visible. This is the first karyotype analysis for $N$. echioides from the $\mathrm{E}$ Mediterranean, and confirms a previous report from Spain (Luque, 1995). This species is characterized by a stable diploid karyotype with the haploid number $n=$ $x=8$. The only substantial difference with respect to the Spanish populations was the absence of SAT-chromosomes.

N. obtusifolia. This is a taxonomically isolated member of sect. Orthocaryum DC. (with erect nutlets) occurring in the E Mediterranean. It showed $2 n=20$, with 10 exact metacentrics, eight metacentrics and only two submetacentrics, all of them of approximately the same small size, ranging from 1.6 to $2.0 \mu \mathrm{m}$ (Fig. 4c). As a result, both asymmetry indexes were substantially lower than in the other taxa examined here. The chromosomes did not show heterochromatic segments. Our observation substantially agrees with two previous reports obtained from Greek populations (Grau, 1971; Constantinidis, 1996), confirming that this species is characterized by a stable diploid karyotype with $n=x=10$. However, we could confirm neither the presence of SAT-chromosomes nor that of supernumerary B-chromosomes reported by Constantinidis (1996).

N. versicolor. This is a Pontic-Caucasian species of the Euxine element, related to N. rosea (M. Bieb.) Link. Like the latter (Strey, 1931; Britton, 1951), it showed a diploid complement of $2 n=16$ small chromosomes measuring $1.7-2.1 \mu \mathrm{m}$ in length (Fig. 5). Its karyotype was largely symmetrical, consisting of six pairs of metacentrics and two submetacentrics. The chromosomes did not show the heterochromatic regions seen in most other species examined. This is the first report for wild-collected Turkish material and it confirms an early count obtained from cultivated material of unknown origin (Guşuleac \& Tarnavschi, 1935).

\section{Hypotheses on chromosome evolution in Nonea}

Table 2 lists the Nonea species whose chromosome number is currently known, in relation to life form, ecological type and chorological element. Though still largely incomplete, these data give some interesting indications about karyological relationships within the genus. First, it is evident that different base numbers occur in Nonea: $x=7,8,9,10$ and 15. If a count of $n=22$ for $N$. caspica from Iran is correct (Aryavand, 1975), $x=11$ should also be added to the series; this requires confirmation. Not many genera in the Mediterranean flora show such wide variation in their base chromosome numbers, emphasizing the morphological and ecological heterogeneity of Nonea. But what is the link between these numbers? According to Luque (1995), they are steps of an ascending dysploid series starting with $x=7$, the ancestral base number also found in Pulmonaria, which is commonly considered the 


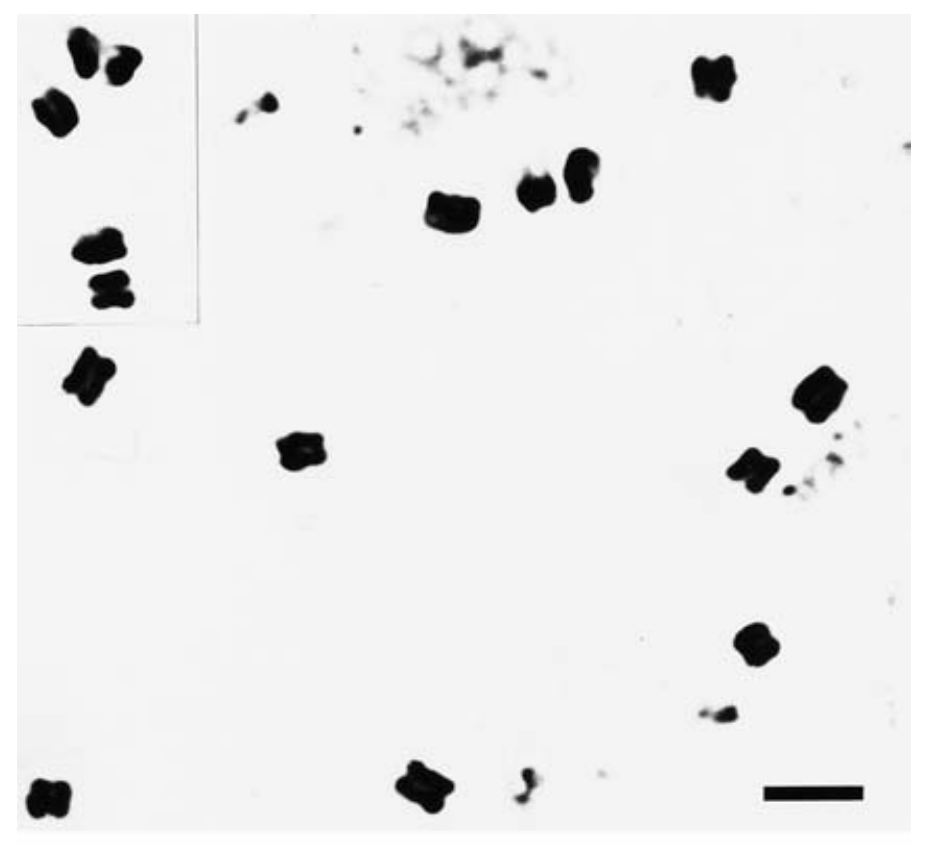

\section{if $\mathbf{H}$ it it it if if if

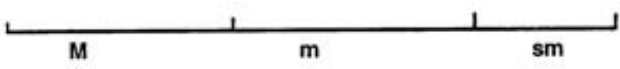

FIG. 5. Metaphase plate and idiogram of Nonea versicolor $(2 n=16)$. Scale bar $=5 \mu \mathrm{m}$.

'sister genus' of Nonea (Johnston, 1924). Our data on the Turkish taxa, however, allow a wider picture to be interpreted and suggest a hypothesis which is shown schematically in Fig. 6 and discussed below.

The base number $x=7$ is found only in the annual species, such as $N$. caspica (Podlech \& Bader, 1974; Ghaffari, 1986, 1996), the related N. pallens (Selvi \& Bigazzi, 1999) and N. lutea (Strey, 1931; Britton, 1951; Grau, 1971). The only exception known to date is the perennial $N$. cesatiana (Fenzl \& Friedr.) Greuter \& Burdet (syn. Paraskevia cesatiana (Fenzl \& Friedr.) W. Sauer \& G. Sauer), a rare endemic with $2 n=28$ occurring in montane forests of the Peloponnese (Sauer \& Sauer, 1980). However, this species seems closer to Pulmonaria than to Nonea, on morphological, ecological and, above all, karyological grounds (Sauer, 1987). Reports of $2 n=14$ for the perennial N. pulla (Malik et al. in Bolkhovskikh et al., 1969) may not be reliable, as they have not been confirmed by subsequent and more detailed observations in which $N$. pulla is characterized as $x=9$ or 10 (Fürnkranz, 1967; JavůrkováJarolímová, 1992); this is further discussed below. The base number $x=8$ is also found only in annual and biennial species, such as $N$. versicolor (Guşuleac \& 
TABLE 2. Chromosome number, life form (A, annual; B, biennial; P, perennial), ecological type and chorological element of the Nonea and Elizaldia species investigated karyologically to date; doubtful numbers are in parentheses. For references see text

\begin{tabular}{|c|c|c|c|c|}
\hline Nonea species & $2 n$ & $\begin{array}{l}\text { Life } \\
\text { form }\end{array}$ & Ecological type & Chorological element \\
\hline anchusoides & 40 & $\mathrm{P}$ & Subalpine, mesophytic & Irano-Turanian \\
\hline atra & 60,59 & B & $\begin{array}{l}\text { Submediterranean, } \\
\text { semi-xerophytic }\end{array}$ & SE Balkan (endemic) \\
\hline caspica & $16,(22), 28$ & A & Continental, xerophytic & Caspian-Anatolian \\
\hline $\begin{array}{l}\text { cesatiana } \\
\quad(=\text { Paraskevia } c .\end{array}$ & 28 & $\mathrm{P}$ & Montane, mesophytic & Peloponnese (endemic) \\
\hline echioides & 16 & A & $\begin{array}{l}\text { Mediterranean, } \\
\text { xerophytic }\end{array}$ & S Mediterranean \\
\hline lutea & 14 & A & Continental, xerophytic & Irano-Turanian \\
\hline macrosperma & 60 & $\mathrm{P}$ & Continental, xerophytic & C Anatolian (endemic) \\
\hline micrantha & 40 & A & $\begin{array}{l}\text { Mediterranean, } \\
\text { xerophytic }\end{array}$ & $\begin{array}{l}\text { SW Mediterranean } \\
\text { (N Africa-S Spain) }\end{array}$ \\
\hline monticola & 20 & $\mathrm{P}$ & Subalpine, mesophytic & Paphlagonian (endemic) \\
\hline obtusifolia & 20 & A & $\begin{array}{l}\text { Mediterranean, } \\
\text { xerophytic }\end{array}$ & SE Mediterranean \\
\hline pallens & 14 & A & $\begin{array}{l}\text { Continental, semi- } \\
\text { xerophytic }\end{array}$ & SE Balkan (endemic) \\
\hline persica & 32,36 & $\mathrm{P}$ & Continental, xerophytic & Irano-Turanian \\
\hline polychroma & 16 & B-P & $\begin{array}{l}\text { Continental, } \\
\text { semi-xerophytic }\end{array}$ & E Anatolian (endemic) \\
\hline pulla & $(14), 18,20$ & $\mathrm{P}$ & $\begin{array}{l}\text { Continental, } \\
\text { semi-xerophytic }\end{array}$ & CE European \\
\hline pulmonarioides & 20 & $\mathrm{P}$ & Alpine, mesophytic & $\begin{array}{l}\text { Pontic Alps (Euxine } \\
\text { endemic) }\end{array}$ \\
\hline rosea & 16 & A & $\begin{array}{l}\text { Continental, } \\
\text { semi-xerophytic }\end{array}$ & Caucasian \\
\hline versicolor & 16 & $\begin{array}{l}\text { A-B- } \\
\text { P }\end{array}$ & $\begin{array}{l}\text { Continental, } \\
\text { semi-xerophytic }\end{array}$ & Pontic-Caucasian \\
\hline vesicaria & 30 & A & $\begin{array}{l}\text { Mediterranean, } \\
\text { xerophytic }\end{array}$ & $\begin{array}{l}\text { SW Mediterranean } \\
\text { (N Africa-S Spain) }\end{array}$ \\
\hline Elizaldia calycina & 30 & A & $\begin{array}{l}\text { Mediterranean, } \\
\text { xerophytic }\end{array}$ & $\begin{array}{l}\text { SW Mediterranean } \\
\text { (N Africa-S Spain) }\end{array}$ \\
\hline
\end{tabular}

Tarnavschi, 1935), the related N. rosea (Strey, 1931; Guşuleac \& Tarnavschi, 1935; Britton, 1951), N. caspica from the Western Himalaya (Vasudevan, 1975), N. polychroma (Selvi \& Bigazzi, 2001), and N. echioides (Luque, 1995), though N. versicolor and N. polychroma tend to be perennant (Popov, 1953; Selvi \& Bigazzi, 2001). The only exception is a possibly tetraploid cytotype of $N$. persica with $2 n=32$ from Iran (Aryavand, 1975; Ghaffari, 1988). It appears that the base number $x=9$ is found, together with $x=10$, only in some $N$. pulla populations (Tarnavschi \& Lungeanu, 1970) and in N. persica from E Anatolia (Selvi \& Bigazzi, 2001). 


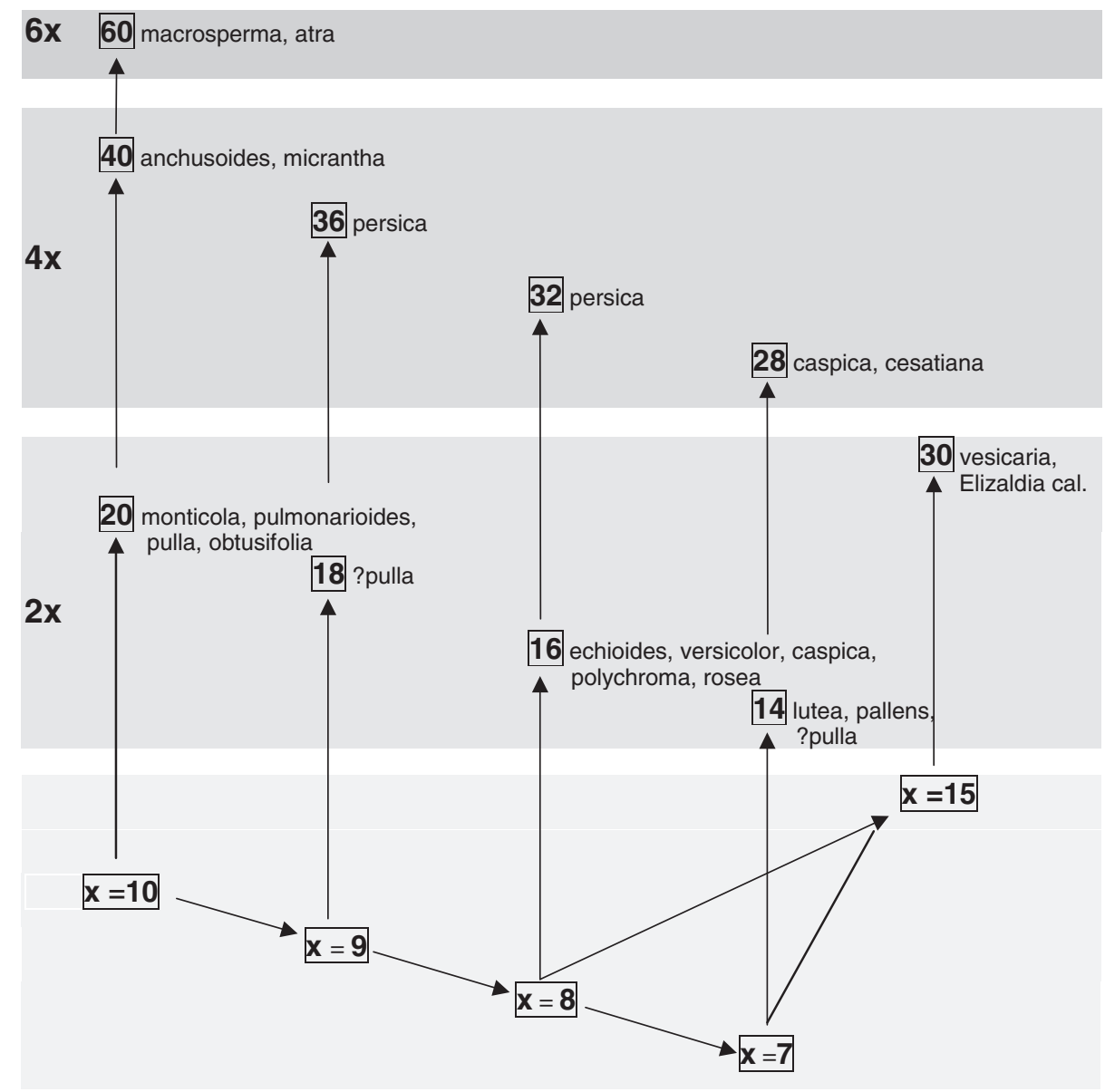

FIG. 6. Diagram of possible karyoevolutionary mechanisms in species of Nonea with different base numbers and ploidy levels.

One of the main points emerging from this study is that the base number $x=10$ is more frequent in Nonea than previously realized. It seems most prevalent in the perennial taxa, being found amongst the annuals only in N. obtusifolia and N. micrantha (Grau, 1971; Luque, 1995), which are two taxonomically isolated species with autapomorphic traits. This base number characterizes at least four distinctive Anatolian endemics from the main centre of diversity of the genus: $N$. monticola (Selvi \& Bigazzi, 2001), N. pulmonarioides, N. anchusoides and N. macrosperma, as well as N. pulla (Fürnkranz, 1967; Javůrková-Jarolímová, 1992; our unpubl. data), and N. atra (Markova \& Ivanova, 1973 under N. pulla var. angustifolia Velen.; Selvi $\&$ Bigazzi, 2001). Of these species, the first two are diploid endemics with $2 n=20$, which grow in alpine and subalpine meadows in restricted areas of the Pontic Alps along the southern Black Sea. They have somewhat larger chromosomes compared 
with the other species, and share an almost identical karyotype, the only difference being the two SAT-submetacentrics in $N$. pulmonarioides. They show the strongest morphological affinities with species in the 'sister' genus Pulmonaria and live in primary, mesic habitats, unlike most of the congeneric taxa. There is reason to suppose that these two species, and perhaps the related Transcaucasian $N$. intermedia and the Kurdish N. macrantha whose karyotypes are still unknown, may be among the basal members of the genus. The occurrence of $x=10$ in these species suggests that this number may be ancestral in Nonea, rather than $x=7$ as suggested for Pulmonaria (Sauer, 1975). This would not support a close phylogenetic relationship between the two genera, although it must be remembered that Pulmonaria is as variable as Nonea in base chromosome number and that $x=10$ also occurs in some taxa, such as the P. australis (Murr) Sauer group (Sauer, 1975).

The tetraploid $(2 n=40)$ and hexaploid $(2 n=60)$ complements found in $N$. anchusoides, $N$. macrosperma and $N$. atra are progressive steps in a euploid series, showing that polyploidy is one of the main speciation mechanisms in the perennial species of the genus. Karyotype analysis suggests that all of these species have an allopolyploid origin following hybridization, now behaving as diploids producing fertile pollen and viable seed. It is hoped that further evidence on the origin of these polyploids may be obtained by studying meiotic behaviour or using techniques such as genomic in situ hybridization (GISH).

Consequently, the numbers $x=9,8$ and 7 are interpreted here as progressive steps in a descending rather than ascending series, as already suggested by Fernandes \& Leitão (1972) before the frequency of $x=10$ was known. Such lower base numbers have possibly arisen through descending dysploidy, although the processes behind this phenomenon remain hypothetical in the absence of in-depth studies. These could include loss of chromosomes following unequal translocation in dividing somatic cells, or, more likely, the centric fusion between two regular chromosomes without loss of requisite genetic material (Jackson \& Casey, 1980). This phenomenon could explain the numbers $2 n=20-19$ (aneusomaty) observed in different cells from the same root tips of $N$. pulmonarioides, and the presence in $N$. atra of cytotypes with $2 n=60$ (Markova \& Ivanova, 1973) and others with $2 n=59$ (Selvi \& Bigazzi, 2001). Several groups exist in which variable chromosome numbers have arisen as a result of dysploidy or aneuploidy (Stebbins, 1971; Favarger, 1999; Stace, 2000), and this phenomenon is thought to have played an important role in the evolution of other Boraginaceae genera such as Pulmonaria (Merxmüller \& Grau, 1969; Sauer, 1987), Omphalodes Miller (Grau, 1967), Mertensia Roth (Vasudevan, 1975) and Cynoglottis (Guşul.) Vural \& Kit Tan (Bigazzi \& Selvi, 2001). If we examine the correlation between chromosome number, life cycle and ecology in Nonea, it appears that descending dysploidy seems to have progressed in parallel with a tendency to shorten the life cycle in relation to the colonization of arid habitats. This may have played a key role in the origin and spread of most xerophytic members of the genus, which are mostly annuals with $x=8$ and $x=7$, possibly derived from mesophytic perennial ancestors with $x=10$. Dysploid reduction associated with the origin of xerophytic 
species from mesophytic ancestors is thought to have played a key role in some groups of Hawaiian plants (Carr, 1998). The annual species of Nonea are almost exclusively diploid, the only exception being $N$. caspica from Iran with $2 n=28$ (Podlech \& Bader, 1974; Ghaffari, 1996). To our knowledge, the only other annual tetraploid species in the genus is $N$. micrantha $(2 n=40)$ from the SW Mediterranean, which has conserved the base $x=10$ (Grau, 1971; Luque, 1995). This supports polyploidy based on $x=10$ as a major mechanism of evolution in Nonea, though mostly in the perennial species. By contrast, radiation and differentiation in the annual taxa have progressed primarily at diploid level. Other annual species include $N$. vesicaria and Elizaldia calycina from North Africa, whose $2 n=30$ probably originated from the backcrossing of two ancestors with $2 n=14$ and $2 n=16$ resulting in the dibasic number $n=15(7+8)$. Meiotic studies by Luque (1995) showed normal pairing and bivalent formation in $N$. vesicaria, confirming its amphidiploid nature as already suggested by Fernandes \& Queirós (1971) and Fernandes \& Leitão (1972).

\section{ACKNOWLEDGEMENTS}

This study was supported by Consiglio Nazionale delle Ricerche, the University of Florence, and by a grant from the International Association for Plant Taxonomy to the first author (F.S.). Two anonymous referees are also acknowledged for their valuable comments and suggestions on the original manuscript.

\section{REFERENCES}

Aryavand, A. (1975). Contribution à l'étude cytotaxonomique de quelques Angiospermes de l'Iran. Bot. Notis. 128: 299-311.

B aytop, A. (1979). Nonea Medicus. In: Davis, P. H. (ed.) Flora of Turkey and the East Aegean Islands 6: 404-414. Edinburgh: Edinburgh University Press.

Bigazzi, M. \& Selvi, F. (1998). Pollen morphology in the Boragineae Bercht. \& J. Presl. (Boraginaceae) in relation to the taxonomy of the tribe. Pl. Syst. Evol. 213: 121-151.

Bigazzi, M. \& Selvi, F. (2000). Stigma form and surface in the tribe Boragineae: micromorphological diversity, relationships with pollen, and systematic relevance. Canad. J. Bot. 78: 388-408.

Bigazzi, M. \& Selvi, F. (2001). Karyotype morphology and cytogeography in Brunnera and Cynoglottis (Boraginaceae). Bot. J. Linn. Soc. 136: 365-378.

Bolkhovskikh, Z., Grif, V., Matvejeva, T. \& Zakharyeva, O. (1969). Chromosome Numbers of Flowering Plants. Leningrad: Akademii Nauk SSSR.

Britton, D. (1951). Cytogenetic studies on the Boraginaceae. Brittonia 7: 233-266.

CARR, G. D. (1998). Chromosome evolution and speciation in Hawaiian flowering plants. In: Stuessy, T. F. \& ONo, M. (eds) Evolution and Speciation of Island Plants, pp. 5-47. Cambridge: Cambridge University Press.

Constantinidis, T. (1996). Mediterranean chromosome number reports no. 749-753. Fl. Medit. 6: 308-312.

D’Amato, F. (1995). Aneusomaty in vivo and in vitro in higher plants. Caryologia 48: 85-103. 
Dyer, A. F. (1979). Investigating Chromosomes. London: Edward Arnold.

Favarger, C. (1999). Contribution à la cytogéographie du Minuartia glomerata

(M.Bieb.) Degen (Caryophyllaceae). Bull. Soc. Neuchątel. Sci. Nat. 122: 27-33.

Fernandes, A. \& Leitão, M. T. (1972). Contribution à la connaissance cytotaxonomique des Spermatophyta du Portugal. V. Boraginaceae. Bol. Soc. Brot., sér. II, 46: 389-405.

Fernandes, A. \& Queirós, M. (1971). Sur la caryologie de quelques plantes récoltées pendant la IIIème réunion de botanique péninsulaire. Mem. Soc. Brot. 21: 343-385.

FürnKRANZ, D. (1967). Einige neue Boraginaceen-Chromosomenzahlen. Österr. Bot. Zeitschr. 114: 341-345.

Ghaffari, S. M. (1986). IOPB Chromosome Number Reports XCIII. Taxon 35: 900-901.

Ghaffari, S. M. (1988). IOPB Chromosome Number Reports XCIX. Taxon 37: 397.

Ghaffari, S. M. (1996). Chromosome studies in some species of Boraginaceae from Iran. Iranian J. Bot. 7: 81-93.

Grau, J. (1967). Primäre und sekundäre chromosomenbasiszahlen bei Omphalodes. Österr. Bot. Zeitschr. 114: 66-72.

Grau, J. (1971). Cytologische Untersuchungen an Boraginaceae. II. Mitt. Bot. Staatssamml. München 9: 177-194.

Guşuleac, M. \& Tarnavschi, I. T. (1935). Cercetari asupra unui hibrid interspecific steril Nonnea lutea Rchb. $\times$ N. rosea Lk. Bul. Fac. Şti. Cernăuţi 9: 387-400.

JACKSON, R. C. \& CASEY, J. (1980). Cytogenetics of polyploids. In: Lewis, W. H. (ed.) Polyploidy: Biological Relevance, pp. 17-44. New York/London: Plenum Press.

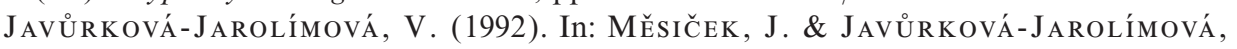
V., List of Chromosome Numbers of Czech Vascular Plants. Praha: Academia.

Johnston, I. M. (1924). Studies in the Boraginaceae. III.1. The Old World genera of the Boraginoideae. Contr. Gray Herb. 73: 42-78.

Levan, A., Fredga, K. \& Sandberg, A. A. (1964). Nomenclature for centromeric position on chromosomes. Hereditas 52: 201-220.

Luque, T. (1989). Estudio cariológico de Boraginaceae españolas - IV. Pulmonaria L., Symphytum L., Pentaglottis Tausch y Borago L. (Boragineae). Bol. Soc. Brot., sér. II, 62: $211-220$

Luque, T. (1995). Karyology of Nonea Medicus (Boraginaceae) in Spain: relationships between genera of Boragineae Barbier \& Mathez (Anchuseae DC.). Bot. J. Linn. Soc. 117: 321-331.

Markova, M. L. \& Ivanova, P. (1973). IOPB Chromosome Number Reports XL. Taxon 22: 285-291.

Merxmüller, H. \& Grau, J. (1969). Dysploidie bei Pulmonaria. Rev. Roum. Biol. (Bot.) 14: 57-63.

Podlech, D. \& Bader, O. (1974). Chromosomenstudien an Afghanischen Pflanzen. II. Mitt. Bot. Staatssamml. München 11: 457-488.

Popov, M. G. (1953). Nonea Medic. In: Komarov, V. L. (ed.) Flora SSSR 19: 237-257. Moskva-Leningrad: Akademii Nauk SSSR

Romero ZArco, C. (1986). A new method for estimating karyotype asymmetry. Taxon 35: $526-530$.

Sauer, W. (1975). Karyo-systematische Untersuchungen an der Gattung Pulmonaria (Boraginaceae). Biblioth. Bot. 131: 1-85.

SAUer, W. (1987). The Pulmonaria dacica group: its affinities with central and south-east European allies and with the genus Paraskevia (Boraginaceae). Pl. Syst. Evol. 155: $257-276$ 
Sauer, W. \& Sauer, G. (1980). Paraskevia gen. nov. mit P. cesatiana comb. nov. (Boraginaceae), eine endemische Gattung Griechenlands. Phyton (Austria) 20: 285-306. Selvi, F. \& Bigazzi, M. (1999). Nonea pallens (Boraginaceae), a new addition to the flora of Turkey. Edinb. J. Bot. 56: 361-369.

Selvi, F. \& Bigazzi, M. (2001). The Nonea pulla group (Boraginaceae) in Turkey. Pl. Syst. Evol. 227: 1-26.

Stace, C. A. (2000). Cytology and cytogenetics as a fundamental taxonomic resource for the 20th and 21st centuries. Taxon 49: 451-477.

Stebbins, G. L. (1971). Chromosomal Evolution in Higher Plants. London: Edward Arnold.

Strey, M. (1931). Karyologische Studien an Boraginoideae. Planta 14: 682-730.

Tarnavschi, I. T. \& Lungeanu, I. (1970). IOPB Chromosome Number Reports XXVIII. Taxon 19: 609-610.

Vasudevan, K. M. (1975). Contribution to the cytotaxonomy and cytogeography of the flora of the Western Himalaya. Ber. Schweiz. Bot. Ges. 85: 210-252.

Received 9 April 2001; accepted after minor revision 15 May 2002 